\title{
The Swedish unemployment insurance - will the Ghent system survive?
}

\section{Introduction}

In all Nordic countries with union-administrated unemployment insurance, referred to as Ghent systems, these systems are under pressure (see Lind 2004 on Denmark; and Böckerman and Uusitalo 2005, and Jokivuori in this issue, on Finland). In Sweden the share of workers directly affiliated to unemployment funds, i.e. without being union members, has increased considerably since the late 1980 s and spread to all groups of wage and salary earners. After some years of growth in the early 1990s union density has declined since 1993, particularly among young workers. This article discusses the significance of the Ghent system and other characteristics of Swedish industrial relations for the still 
very high union density in Sweden. On the eve of the September 2006 parliamentary elections, the non-socialist opposition alliance is proposing far-reaching changes to the unemployment insurance. This article also discusses the possible consequences of this.

\section{Ghent systems and union density}

In Denmark, Finland and Sweden trade unions have a prominent role in the management of unemployment insurance. From an international perspective, union density in these three countries is very high. As much as $70-80 \%$ of all workers are union members. In contrast, trade unions in another Nordic country, Norway, comprise less than $55 \%$ of the workers. Combined with the fact that Norwegian unions have since 1938 been dissociated from the administration of unemployment insurance this suggests a close connection between union density and the model of unemployment insurance (see Kjellberg 1983: 159-163, 204205; Rothstein 1992). Up until 1938 the Ghent system was applied also in Norway. It is still partly in place in the homeland of the system, Belgium, where union density - as in Norway - is about $55 \%$.

On the other hand, the significance of union unemployment funds should not be exaggerated. The influence of other circumstances upon the ability of unions to recruit and keep members is already apparent from the fact that union density among industrialised non-Ghent countries varies from less than $10 \%$ (France) to $52-53 \%$ (Norway) and among Ghent countries from $55 \%$ to $80 \%$. Secondly, particularly in Sweden, a substantial, and growing, proportion of workers are affiliated to union unemployment funds without being union members.
During the 1980s this phenomenon expanded among Swedish private sector white-collar workers (Table 1). In the 1990s it spread to blue-collar workers and to public sector employees. At the end of 2005 every seventh member of a union-led unemployment fund was not a union member.

Only a small minority of those directly affiliated to unemployment funds rejects union membership for ideological reasons (Kjellberg 2001: 164-165, 169-174, 390). More important are financial reasons: non-union members only have to pay a relatively small fee to the unemployment fund while union dues (which include fund fees) are substantially higher. Often, the costs and benefits of union membership are weighed against each other. Dissatisfaction with overly high dues and too low benefits is widespread among blue-collar non-members (Nelander and Goding 2002: 52-58). In 2002 no less than six out of ten blue-collar workers directly affiliated to unemployment funds were former union members. Secondly, when interviewed, many non-union white-collar workers, whose union fees in general are considerably lower than those of bluecollar workers, stated they managed well without the assistance of any union (Kjellberg 2001: 173, 177). Thirdly, workers directly affiliated to unemployment funds are strongly over-represented at workplaces without a union organisation (ibid.: 124-130, 174-177). Every second non-union blue-collar worker is found at workplaces without union representatives compared to less than $20 \%$ of union members (Nelander and Goding 2002: 55).

Thereby we touch upon a second distinctive feature of Nordic industrial relations that promotes a high or very high density, i.e. its combination of centralisation and 
decentralisation. Centralisation refers to industry-wide agreements between national unions and employers' associations, the latter usually with a very high coverage with respect to workers employed. Starting from these national agreements, negotiations about wages and other employment conditions follow at local level, where the extensive union workplace organisation plays a key role, making up the decentralised component of Nordic industrial relations. The result is a very high coverage of collective agreements, in Sweden about $85-90 \%$ of private sector workers, despite the absence of state extension mechanisms. Collective agreements and industrial relations regulated by the labour market parties themselves (not by the state) are cornerstones of the traditional Nordic model, in addition to the combined centralisation and decentralisation. Through their direct presence at workplace level Nordic trade unions have a high profile among their members while producing visible results, thereby facilitating the recruitment of members in different ways.

In general, union workplace organisations in Sweden are stronger among blue-collar workers than among white-collar workers. It is certainly not a coincidence that whitecollar workers are more frequently directly affiliated to unemployment funds than their blue-collar colleagues. As much as $20 \%$ of the members of the fund belonging to the largest white-collar union (SIF, Swedish Union of Clerical and Technical Employees) are not union members. The corresponding figure for the fund associated with the second largest private sector white-collar union (HTF, Union of Commercial Salaried Employees) is no less

Table 1: Non-union members in some union unemployment funds 1980-2005 (\%)

\begin{tabular}{|l|c|c|c|c|c|c|c|c|c|c|}
\hline Unemployment fund & $\mathbf{1 9 8 0}$ & $\mathbf{1 9 8 5}$ & $\mathbf{1 9 8 7}$ & $\mathbf{1 9 9 0}$ & $\mathbf{1 9 9 3}$ & $\mathbf{1 9 9 5}$ & $\mathbf{1 9 9 7}$ & $\mathbf{1 9 9 9}$ & $\mathbf{2 0 0 3}$ & $\mathbf{2 0 0 5}$ \\
\hline Blue-collar, private sector & & & & & & & & & & \\
\hline Paper (LO) & 0 & 0 & 0 & 0 & 0 & 0 & 0 & 1 & 1 & 1 \\
\hline Metal (LO) & & & & 1 & 2 & 4 & 5 & 6 & 6 & 7 \\
\hline Commercial (LO) & & & 3 & 4 & 10 & 12 & 15 & 17 & 17 & 18 \\
\hline Transport (LO) & & & 4 & & 10 & 12 & 13 & 16 & 18 & 19 \\
\hline Hotel and Restaurant (LO) & & & & 1 & 5 & 8 & 12 & 14 & 18 & 23 \\
\hline Blue-collar, public sector & & & & & & & & & & \\
\hline Municipal (LO) & 0 & 0 & 0 & 1 & 2 & 2 & 3 & 4 & 5 & 7 \\
\hline White-collar, private sector & & & & & & & & & & \\
\hline SIF (manufact. ind., TCO) & 1 & 5 & 6 & 9 & 15 & 16 & 17 & 19 & 19 & 20 \\
\hline HTF (private serv., TCO) & 1 & 9 & 10 & 14 & $22^{*}$ & $28 * *$ & 29 & 30 & 30 & 30 \\
\hline White-collar, public sector & & & & & & & & & & \\
\hline Municipal (TCO) & & 1 & 1 & 1 & 2 & 3 & 5 & 7 & 9 & 11 \\
\hline White-collar, mixed & & & & & & & & & & \\
\hline AEA (SACO) & & $2 * * *$ & 2 & 4 & 8 & 9 & 10 & 13 & 17 & 19 \\
\hline All union funds & & & & & 6 & 7 & 9 & 10 & 12 & 14 \\
\hline All union funds + Alfa & & & & & & & & 11 & 14 & 16 \\
\hline
\end{tabular}

31 December each year, except 1993 (31 August), *1992, **1996, ***1986.

Sources: Kjellberg 2001 and the National Inspectorate of Unemployment Insurance. 
than $30 \%$. The HTF workplace organisation is distinguished by having less strength and coverage than that of SIF. Both SIF and HTF are affiliated to the white-collar confederation TCO (Swedish Confederation of Professional Employees).

The other white-collar confederation, SACO (Swedish Confederation of Professional Associations), is smaller but is expanding faster. The blue-collar confederation LO (Swedish Federation of Trade Unions) still comprises every second union member, although its share of total union membership has been declining for a long time due to the changed composition of the labour force. Through its division into LO (bluecollar), TCO (white-collar) and SACO (university graduated), Sweden has the most socially segregated trade union movement among industrialised countries (Kjellberg 2000: 530-531). Already at an early stage Swedish white-collar workers preferred politically independent unions to the social democratic LO unions. Secondly, LO for a number of reasons was not interested in organising white-collar workers. If it had been, a certain number of white-collar workers would have probably abstained from union membership rather than joining social democratic unions dominated by blue-collar workers. No merger across the collar-line has hitherto occurred in Sweden (Ioannou and Kjellberg 2005: 347). This distinctive feature of Swedish unions has promoted the very high union density, which is on average about the same for white-collar and bluecollar workers. In 2004 as much as $78 \%$ of the former and $79 \%$ of the latter were union members. Within the private sector the shares were $70 \%$ and $75 \%$ respectively (yearly averages of employed workers; Labour force survey 2004).
Among blue-collar workers direct affiliation to unemployment funds is also highest in industries with relatively weak workplace organisations, many small workplaces and high labour turnover. Thus, non-union members make up about every fifth member in the funds associated with the LO unions organising workers in commerce, transport workers, and hotel and restaurant workers (Table 1$)^{1}$. In spite of this, the importance of unemployment funds for recruiting union members seems paradoxically to be the largest in just this type of industry because of the relatively weak market position of workers: a high share of non-skilled workers, many parttimers, high labour turnover, etc (Western 1999: 129). The argument is of course strengthened if other motives for joining unions are missing, for example, a large share of workers at small workplaces without much union activity. Comparisons between Ghent and non-Ghent countries give further support for the above hypothesis. In spite of a high proportion of workers directly affiliated to unemployment funds in Swedish commerce, the cleavage in union density between Sweden and Norway is particularly evident in an industry like this: about $63-66 \%$ of union members in Swedish commerce compared to only about $20 \%$ in Norway (Kjellberg 2001: 260). Only some 5\% of American and $10 \%$ of British workers in the commerce sector are union members. Furthermore, when the Swedish unemployment insurance was extended to parttimers (at least 17 hours/week) in 1974 union density among this category of workers increased sharply (Kjellberg 2001: 91-93, 99). As mentioned above, commerce contains a large number of parttime workers, many of whom are women.

1 In Sweden most workers within commerce, hotel and restaurants are considered as blue-collar workers. 
The strongest union workplace organisations are found among blue-collar workers in manufacturing industry $(88 \%$ union density in 2004), although they have often lost some of their former strength. The members of the Swedish Paper Workers' Union are concentrated at a relatively small number of large paper and pulp mills (often dominating local communities), which promotes strong workplace unions and high union density. Not surprisingly, the share of non-union members is still very low in the unemployment fund associated with the union (Table 1, above).

\section{Declining union density and increasing share of non-union members in unemployment funds}

Since 1993 union density in Sweden has declined from $85 \%$ to $79 \%$ (Table 2), while direct affiliation to union unemployment funds has climbed continuously (Table 1). Including the independent Alfakassan, the share of non-union members in 2005 was no less than $16 \%$ or every sixth member in funds for wage and salary earners. As part of a compromise between social democrats and liberals in the mid1930s, non-union members were given the right to join unemployment funds already from the outset of the Swedish Ghent system (Rothstein 1992: 48). Unions for a long time, however, made it difficult for non-members to enter funds without joining a union. Until check-off (i.e. deduction of union dues from the salary) was introduced and collectors of union dues were abolished it was considered as disloyal to pay just the fee to the unemployment fund. Furthermore, that this was a possibility was not widespread knowledge. In the early 1980s the non-socialist evening paper Expressen launched a campaign to encourage workers to join unemployment funds without becoming union members. Such behaviour gained ground in the first instance among private sector white-collar workers in Stockholm and other big cities. At the end of the decade as much as 13$14 \%$ of the HTF and SIF funds in Greater Stockholm were made up by non-union members (Kjellberg 2001: 113-116).

The fall in union density since 1993 is particularly marked among young workers (Table 2). A contributory factor is that every second worker aged 16-24 today has a temporary job compared to every third worker 15 years ago. Also, changed attitudes are part of the picture. In the early 1990s both union density and direct affiliation to funds rose due to the sharp swing from an extremely tight labour market in the late 1980s to the deepest depression since the 1930s. Between 1990 and 1991

Table 2: Union density by age in Sweden 1990-2004 (\%)

\begin{tabular}{|l|c|c|c|c|c|}
\hline Age & $\mathbf{1 9 9 0}$ & $\mathbf{1 9 9 3}$ & $\mathbf{2 0 0 4}$ & $\mathbf{1 9 9 0 - 2 0 0 4}$ & $\mathbf{1 9 9 3 - 2 0 0 4}$ \\
\hline $16-24$ & 62 & 69 & 48 & -14 & -21 \\
\hline $25-29$ & 78 & 81 & 70 & -8 & -11 \\
\hline Sum 16-29 & 69 & 76 & 60 & -9 & -16 \\
\hline $30-44$ & 85 & 86 & 80 & -5 & -6 \\
\hline $45-64$ & 88 & 89 & 86 & -2 & -3 \\
\hline Sum 16-64 & 81 & 85 & 79 & -2 & -6 \\
\hline
\end{tabular}

Note: Employed workers' yearly averages. Full-time students working part-time excluded. Labour force surveys. 
unemployment increased from $1.7 \%$ to 9.0\% (OECD 2005). Most workers now found it necessary to belong to an unemployment fund in one way or another. Not least young workers acted accordingly, as they were particularly hit by the depression. The unions devoted much energy to negotiations about redundancies. Through this legal right dating back to the new labour legislation of the 1970s Swedish unions in insecure times thus fulfil another important task in the eyes of the workers, i.e. in addition to that of administrating unemployment funds. Consequently, membership recruitment is promoted in more than one way in times of depression. Here Sweden differs from Denmark, which has no legislation about job security, but on the other hand very generous unemployment benefits.

In the event, direct affiliation to unemployment funds among some groups of white-collar workers almost exploded in the early 1990s. In Stockholm almost four out of ten young members (under 29 years of age) of the HTF fund were not union members at the end of 1992.

More seriously, the mass unemployment of the 1990s weakened union workplace organisations in their fight for 'good jobs', training and an improved work environment. Following the decline in unemployment after 1993 lean production methods continued, decreasing the time available for union activities at the workplace. The attenuated workplace organisation of many unions has made it more difficult to recruit and keep members. As a result of the failure of the employers to get rid of national collective agreements, however, bargaining strength at workplace level was kept relatively intact, stressing the importance of combined centralisation and decentralisation.

When Swedish trade union members were asked in 2002 to give their view on the importance of 20 specified union tasks, 'job security', 'wages', 'protection against income losses, for example in the case of sickness and unemployment', 'working environment' and 'equality between women and men' appeared as the top five (Nelander and Goding 2002: 16-22). Members of the white-collar confederations TCO and SACO gave income protection (including unemployment insurance) the lowest priority of the top five. Less than $60 \%$ of SACO members considered it 'very important'. With respect to wages the corresponding share was above $75 \%$. In contrast, LO members did not make a big difference between the top five tasks, which were all considered by 75 $80 \%$ of the members as 'very important', with job security and wages slightly ahead of the other three.

Swedish unemployment funds seem to have less value than Danish ones for union recruitment, at least in the early $1990 \mathrm{~s}^{2}$. When open questions in 1993 were used mapping out the dominating motive for joining a union or being affiliated to a

2 According to a Danish 1992 survey, access to an unemployment fund was the outstanding motive for union membership among LO members (see Lind 2004). In 2002 that was no longer the case (LO-Denmark 2005: 67-79). Possible explanations for this change of attitude are that unemployment in 2002 was lower and less conspicuous in the political debate than ten years earlier, and that the knowledge of the possibility of joining an unemployment fund without becoming a union member was now more widespread. The Danish 2002 survey, however, also asked the LO members about the most important union tasks. When evaluating 18 specified tasks $62 \%$ 'strongly agreed' on 'level out wage differences between men and women', $61 \%$ on 'improve working environment', $51 \%$ 'secure highest possible wages for the members', also $51 \%$ 'give personal assistance to the members', followed by 50\% 'work for better job security' (LO-Denmark 2005: 93-110). None of the specified tasks corresponded to 'protection against income losses' in the 2002 Swedish survey. 
union very few Swedish union members mentioned unemployment funds (Kjellberg 2001: 162, 387-389). Nine out of ten Swedish workers today are affiliated to unemployment funds but their union recruitment value appears to have been devalued. The funds increasingly are looked upon as an alternative to rather than as a motive for union membership. This also applies to the AEA fund run by SACO (and thus common for all SACO unions, and since 2006 also including a TCO union ${ }^{3}$ ). Despite the dominance of public sector employees among the university educated almost every fifth AEA member is not a union member.

In a theoretical analysis Holmlund and Lundborg (1999) found a positive impact of Ghent systems on union density with the degree of government subsidies as one of the crucial factors. They concluded, however, that a richer model was required to explain why some workers choose direct affiliation to unemployment funds.

For Finland, Böckerman and Uusitalo (2005; see also Jokivuori, in this issue) argue that the emergence of the independent unemployment fund YTK was the main reason for the sharp decline in union density (from $84 \%$ to $73 \%$ ) between 1993 and 2002. As in Sweden union density increased during the deep depression in the early 1990 s only to reverse downwards when unemployment began to decline. In both countries the fall was par- ticularly marked among young workers. The Finnish independent fund, introduced in 1992, expanded rapidly to include more than 250000 members by the end of $2005^{4}$. Together with the apparent hesitation of Finnish workers to join union-led funds without being union members, the low fee of YTK explains its success.

Today the share of non-union members among fund members is about the same in Finland (15\% in 2004) $)^{5}$ and Sweden (16\% in 2005), but the role of independent funds differs sharply. While the Swedish unionrun funds contain as much as $14 \%$ nonunion members (Table 1), the corresponding share in Finland is just $3 \%^{6}$. Also in Denmark direct affiliation to union-led funds appears to be limited with the Christian fund as an exception. About half of its 160000 members are not affiliated to the Christian union.

When the Swedish equivalent to Finnish YTK, the independent Alfa-kassan, started in 1998 the significance of the Ghent system for union recruitment was already eroded by the relatively large share of non-union members affiliated to union-led unemployment funds ${ }^{7}$. At the end of 2005 this group embraced no less than 505000 workers (14\% of members in union-led funds) or considerably more than the 77000 members in Alfakassan, which also includes some selfemployed/employers. In 1997 the Federation of Unemployment Insurance Funds (SO) by law was instructed to start the

3 In January 2006 the TCO union organising nurses changed unemployment fund to AEA. Today, AEA, together with the fund of municipal workers (LO), is the largest unemployment fund in Sweden (each with about 600000 members).

4 In addition, a non-union fund for some business crafts has existed since 1968 (17000 members in 2004).

5 Calculations from statistics obtained from the Finnish Insurance Supervisory Authority.

6 The share of non-union members, however, is $10 \%$ in the Finnish unemployment fund for university graduates, but just $0.1 \%$ in the metalworkers' fund and $1.5 \%$ in the fund for white-collar workers within manufacturing industry (in 2004 ).

7 In the second half of 1994 there existed four state unemployment funds, introduced by the non-socialist government. Already from the beginning of 1995 they were abolished by the new social democratic government. The four funds might be considered as predecessors to the Alfa-kassan. The social democrats introduced the latter in the first instance to administer the basic unemployment insurance aimed at those who did not qualify for income benefits (see below). 
independent Alfa-kassan. SO is an umbrella organisation of all union-run funds, Alfa-kassan and the four unemployment funds aimed exclusively at selfemployed/employers. The Confederation of Swedish Enterprise is among the founders of one of the latter.

The membership fee for Alfa-kassan (1 $380 \mathrm{SEK} /$ year) is about the same as directly-affiliated members pay to unionled unemployment funds (1 euro is about 9.3 SEK). Consequently, as in Finland, there is no economic incentive to switch from union funds to the independent fund. Union members pay less, but they also have to pay union dues (which are much higher). In recent years the union-run funds have become somewhat more independent by making a more clear demarcation between union administration and fund administration (SO 09.12.2004). Since 2002 they have the same status as state agencies when applying the laws in detail regulating their operations, including the principles of secrecy and public access to official records.

The union-run funds have a long history. That of the Metalworkers' Union was founded in 1897 and was transformed into a state-supported fund in 1942 (Metalls Akassa 1977; Erici and Roth 1981: 273). Fear of negative effects of state regulation delayed the decision to join the Swedish Ghent system, introduced in 1935 and reformed in 1941. As late as 1940 only about $20 \%$ of LO members belonged to a state-supported unemployment fund (Edebalk 1996: 129).

Today membership fees cover the administration costs of funds and only a smaller part of benefits paid to unemployed. About $90 \%$ of benefits are financed by the state.
Likewise, the state runs the local employment offices, which cooperate closely with unemployment funds. If an unemployed person rejects an offer of a suitable work the labour exchange informs the fund. After enquiring as to the reasons why, the fund has to decide whether to use sanctions like reduced or suspended benefit.

Besides an income-related benefit the unemployment insurance also contains a basic insurance (since 1998). To be entitled to the income-related benefit at least 70 hours work for at least six months during a 12-month period are required. Consequently part-timers with an average working week of at least 17 hours are covered. Those not fulfilling this receive support from the basic insurance. All 37 unemployment funds administrate both kinds of benefits. Alfa-kassan in addition provides basic insurance to those not affiliated to any fund.

\section{The hollowing-out of the unem- ployment insurance}

Irrespective of form of insurance the benefit period is 60 weeks, which in practice can be followed by another period(s) after passing through activity programmes provided by the National Labour Board. No benefit is paid for the first five days of unemployment. In 1993 the income-related benefit was reduced from $90 \%$ to $80 \%$ of previous earnings. Six years later it was further reduced to $75 \%$. After consolidation of public finances the benefit was restored to $80 \%$ in the autumn of 1997. Over the past 15 years the reforms of the Swedish unemployment insurance thus exhibit a somewhat pro-cyclical pattern (Bennmarker et al. 2005: 13). There is a ceiling on the benefit level resulting in lower replacement rates for those with high earnings. This ceiling was also 
reduced in 1993 to be adjusted upwards in 2001-2002 to prevent too large a gap between benefits and rising nominal wages. Since then a growing share of the unemployed entitled to income insurance, in 2005 almost every second unemployed, receive less than $80 \%$ of their previous wages $^{8}$. Therefore several white-collar unions by agreement with insurance companies offer their members collective and individual complementary insurance (IAF 14.10.2004). Both the hollowing out of benefits and the introduction of additional forms of insurance of course undermine the legitimacy of the traditional Ghent system. For a rather long time there have also existed collective agreements on supplementary benefits for white-collar and public sector workers. Not until 2004 did LO and the Confederation of Swedish Enterprise conclude a similar agreement for private sector blue-collar workers, although a less generous predecessor had existed.

\section{Will the Swedish Ghent system survive?}

There is a debate among economists and politicians on the effects of the relatively high benefit levels (for low-income earners) on the incentives to find new jobs. On the eve of the September 2006 parliamentary elections the four non-socialist parties propose reduced benefit levels (from $80 \%$ to $70 \%$ after 200 days and just $65 \%$ under activity programmes), a reduced benefit ceiling from 730 to $680 \mathrm{SEK} /$ day, multiplied fees for membership of unemployment funds and the introduction of compulsory unemployment insurance (Allians för Sverige 31.08.2005). In addition, parttimers would have to work at least 20 hours per week to receive benefits in the event of unemployment. The proposal, a compromise between the four opposition parties forming an alliance in 2005, is not entirely clear-cut. It is not clear as to whether the link between trade unions and unemployment funds will be broken. In any case, under the proposal union membership would be less attractive as union dues would also have to be raised considerably. Furthermore, no fee would be tax deductible (today $25 \%$ of union dues and $40 \%$ of unemployment fees are deductible).

According to calculations by LO, several members of unemployment funds would be hit by a more than sixthfold net increase in their fee, more precisely, from $60 \mathrm{SEK} /$ month (100 SEK - tax reduction $40)$ to $400 \mathrm{SEK} /$ month (Andersson et al. 2006). The exact rise in the fee depends on the rate of unemployment among members of the fund in question. The underlying rationale is to push unions towards modest wage claims in industries with high unemployment. Since 1989 the funds distribute membership fees in a solidaristic way. Together with the high degree of state subsidies, this means that virtually no connection exists between fees and rate of unemployment among the members of a fund (Holmlund and Lundborg 1999: 403).

The proposal by the Alliance for considerably increased fees, particularly in industries hit by severe unemployment, but also the reduced benefits, might influence wage formation. LO fears that reduced benefits might depress the wages of already low-paid workers, as some unemployed would have to accept jobs with very low

8 On average $45 \%$ of unemployed receive less than $80 \%$. In the first 100 days, when the ceiling is 730 SEK/day the share is $36 \%$. After 100 days the ceiling is reduced to 680 SEK/day resulting in as much as $49 \%$ receiving less than $80 \%$ (SO 06.12.2005). 
wages (Andersson et al. 2006). The result might be increased wage rifts and a shift of power to the advantage of employers on the labour market.

According to a bill (Politik för arbete och välfärd) submitted in October 2005 by Moderaterna, the largest non-socialist party, the individual worker in a compulsory system would have freedom to choose their fund, as is the case under the revised Danish system (Lind 2004) ${ }^{9}$. Today a Swedish non-union worker can join the independent Alfa-kassan or the fund corresponding to her/his employment or the small syndicalist fund (about $55 \%$ of the members in this fund are directly affiliated). Conversely, according to existing law (in force since 1997) union members have the right to abstain from membership of unemployment funds even if the requirements for membership are fulfilled ${ }^{10}$. In a system with complete freedom many workers probably would minimise their costs by choosing funds with low fees, which would undermine the connection between unions and unemployment funds. In the programme presented by the Alliance in August 2005 nothing is said about freedom of choice. When the Alliance in October 2005 presented its common economic policy the spokesman for the Liberal Party in economic matters, Karin Pilsäter, however, declared that it would be up to the individual to choose a fund in a compulsory system (Sveriges Radio 03.10.2005).

\section{Conclusion}

Like the other Nordic Ghent countries, Denmark and Finland, Sweden is distinguished by its extremely high union density. Part of the explanation is found in the close connection between unions and unemployment funds. For many years, workers took it for granted that union membership was a prerequisite for access to an unemployment fund. This circumstance, however, was far from the only one promoting a high union density. Other characteristics of Nordic industrial relations also have to be taken into consideration, particularly as their interaction in general exerted a positive influence on the rate of unionisation. This article has only touched upon some of the key components, like the combined centralisation and decentralisation and the high degree of regulation by the labour market parties themselves. Without separate unions for white-collar and blue-collar workers, union density would have certainly been considerably lower among whitecollar workers. The most pronounced social segregation in this respect is found in Sweden, while demarcation conflicts and intense membership competition have for a long time dominated the relations between LO-Norway and the Norwegian counterpart to the Swedish white-collar confederation TCO.

Since 1993 Swedish union density has declined, particularly among young workers. In the second half of the 1980s and the

9 From September 2002 unemployment funds in Denmark can recruit across the entire labour market and thus compete with all other funds. Today 7 of the 33 Danish funds recruit wage and salary earners from the whole of the labour market (4 of them also self-employed/employers; January 2006). Already before 2002 the Christian fund was permitted by law to do so. Up to 2005 relatively few individuals, however, have made use of the new option (Arbejdsdirektoratet (2005), pp. 68-69) although membership in the most expensive fund for wage and salary earners in November 2005 was more than twice as costly as that in the cheapest fund open for all workers.

10 Since the mid-1990s membership of the Metalworkers' Union does not automatically lead to membership of the Metalworkers' unemployment fund even if the conditions for entry are fulfilled. On the other hand, all union members have to pay full union dues. In contrast, members of the white-collar union in manufacturing industry, SIF, who abstain from fund membership have reduced union dues. 
early 1990s the changing level of unemployment had a strong impact upon union density, which fell after the mid-1980s to rise again when the tight labour market in a few years turned into one of mass unemployment. In the 1980s the share of workers directly affiliated to unemployment funds, i.e. without being union members, increased among private sector white-collar workers, particularly in big cities. Many thought they managed well without the assistance of any union, but for safety's sake felt it best to belong to a union unemployment fund. The sharp shift to depressed times was followed by both rising union density and by an accelerated share of non-union members in unemployment funds. Direct affiliation to funds now multiplied also among bluecollar workers. Today about every fifth member of the LO funds within private services is not a union member. In the 1990s direct affiliation spread to LO and TCO public sector funds. Among university graduates direct affiliation is now also widespread. By contrast with Finland, it was not the introduction of an independent fund that led to a higher share of non-union members in Swedish funds. When the independent Alfakassan started in 1998, direct affiliation to union-run funds was already extensive and dispersed among all categories of workers, although to a varying degree.

It is not only the rising share of non-union members in unemployment funds that is eroding the Swedish Ghent system. Swedish unemployment insurance is relatively generous, but benefit levels are being increasingly hollowed-out as the ceiling of the insurance lags behind wage increases. The introduction of supplementary unionrun insurances, which are 'selective' by being exclusively for union members, has not halted the rising share of non-union members in unemployment funds.
In the event of a non-socialist victory in the September 2006 parliamentary elections the present Ghent system would be radically changed by the introduction of compulsory unemployment insurance, multiplied fees and reduced benefits. By contrast, LO and the social democrats propose an increased benefit ceiling to prevent the hollowing-out of the system.

\section{References}

Allians för Sverige, Press communiqué, Bankeryd, 31 August 2005.

Andersson, D., J. Lindblad and A.-K. Löfgren (2006) Gemensam arbetslöshetsförsäkring?, Stockholm: LO.

Arbejdsdirektoratet (2005) Benchmarking af arbejdsløshedskasserne 2005, Copenhagen: Arbejdsdirektoratet.

Bennmarker, H., K. Carling and B. Holmlund (2005) 'Do benefit hikes damage job finding? Evidence from Swedish unemployment insurance reforms', IFAU Working Paper 2005: 22.

Böckerman, P. and R. Uusitalo (2005) 'Union Membership and the Erosion of the Ghent System: Lessons from Finland', Helsinki: Labour Institute For Economic Research, Discussion paper 213.

Edebalk, P. (1996) Välfärdsstaten träder fram. Svensk socialförsäkring 1884-1955, Lund: Arkiv.

Erici, B. and N. Roth (1981) Arbetslöshetsförsäkringen $i$ Sverige 1935-1980, Stockholm: Arbetslöshetskassornas samorganisation.

Holmlund, B. and P. Lundborg (1999) 'Wage bargaining, union membership and the organisation of unemployment insurance', Labour Economics, 6, 397-415.

IAF (2004) Rapport från Inspektionen för arbetslöshetsförsäkringen, 14.10.2004.

Ioannou, C. and A. Kjellberg (2005) 'Confederations and Mergers: Convenience Rather Than True Love', in J. Waddington (ed.) Restructuring Representation, Brussels, P.I.E.- Peter Lang, 337-360.

Kjellberg, A. (1983) Facklig organisering i tolv länder, Lund: Arkiv. 
Kjellberg, A. (2000) 'The Multitude of Challenges Facing Swedish Trade Unions', in J. Waddington and R. Hoffmann (eds.) Trade Unions in Europe, Brussels: ETUI, 529-573.

Kjellberg, A. (2001) Fackliga organisationer och medlemmar i dagens Sverige, Lund: Arkiv.

Lind, J. (2004) 'The restructuring of the Ghent model in Denmark and consequences for the trade unions', Transfer, 10 (4), 621-625.

LO-Denmark (2005) LO-Dokumentation (2005) Copenhagen: LO-Denmark, December 2005.

Metalls A-kassa (1997) Metalls A-kassa 100 år, Stockholm: Metalls A-kassa 1997.

Nelander, S. and I. Goding (2002) Röster om facket och jobbet, Report 1. Stockholm: LO.

OECD (2005) Employment Outlook 2005, OECD: Paris.

Politik för arbete och välfärd, Bill submitted by the Moderates (Swedish Conservative Party) to the Riksdag (2005/06:m010).

Rothstein, B. (1992) 'Labor-market institutions and working-class strength', in S. Steinmo et al. (eds.) Structuring politics, Cambridge: CUP, 33-56.

SO (2004) Rapport från Arbetslöshetskassornas samorganisation, 09.12.2004.

SO (2005) Rapport från Arbetslöshetskassornas samorganisation, 06.12.2005.

Sveriges Radio 2005-10-03 (talk by Karin Pilsäter at press conference 3 October 2005 reproduced in the news magazine 'Dagens eko').

Waddington, J. and R. Hoffmann (eds.) (2000) Trade Unions in Europe, Brussels: ETUI.

Waddington, J. (2005) (ed.) Restructuring Representation, Brussels, P.I.E.- Peter Lang.

Western, B. (1999) Between Class and Market, Princeton: PUP.

\section{Anders Kjellberg}

National Institute for Working Life and University of Lund, Sweden

E-mail: anders.f.kjellberg@niwl.se 